\title{
FROM THE FACTORY TO SOCIAL NETWORKS: PARALLEL AND PARADOX BETWEEN LIFE AT WORK AND PRIVATE LIFE
}

\section{DA FÁBRICA ÀS REDES SOCIAIS: PARALELO E PARADOXO ENTRE A VIDA NO TRABALHO E A VIDA PRIVADA}

\section{MÁRCIO TÚLIO VIANA}

Pós-Doutor junto à Universidade de Roma I La Sapienza e à Universidade de Roma II Tor Vergata; Doutor em Direito pela Universidade Federal de Minas Gerais; Graduado em Direito pela Universidade Federal de Minas Gerais; É Professor Adjunto IV da Pontifícia Universidade Católica de Minas Gerais; Foi Professor Associado da Universidade Federal de Minas Gerais; Desembargador aposentado do Tribunal Regional do Trabalho da 3ํRegião. E-mail: tgviana1@gmail.com.

\section{MARIA CECÍLIA MÁXIMO TEODORO}

Pós-Doutora em Direito do Trabalho pela Universidade de Castilla-La Mancha com bolsa de pesquisa da CAPES; Doutora em Direito do Trabalho e da Seguridade Social pela USP; Mestre em Direito do Trabalho pela PUC/MG; Graduada em Direito pela PUC/MG; Professora de Direito do Trabalho do Programa de Pós-Graduação em Direito e da Graduação da PUC/MG; Professora convidada do Mestrado em Direito do Trabalho da Universidade Externado de Colômbia; Pesquisadora; Coordenadora do Grupo de Pesquisa Retrabalhando o Direito - RED, que integra a Rede Nacional de Grupos de Pesquisas e Estudos em Direito do Trabalho e da Seguridade Social RENAPEDTS. Advogada. Autora de livros e artigos. E-mail: cecimax@pucminas.br.

\section{KARIN BHERING ANDRADE}

Mestranda na Linha de Pesquisa Trabalho, Democracia e Efetividade na Pontifícia Universidade Católica (PUC- Minas). Possui graduação em Direito pela Faculdade 
Milton Campos. Professora de Deontologia Jurídica no curso preparatório para a OAB do Centro de Estudos Isadora Athayde. Pesquisadora do Grupo de Pesquisa e Estudos em Direito do Trabalho RED - Retrabalhando o Direito, da Pontifícia Universidade Católica de Minas Gerais. Atualmente é membro da Comissão de Direitos Sociais e Trabalhistas da Ordem dos Advogados do Brasil de Minas Gerais (OAB/MG). Atualmente é membro da Comissão de Direitos Humanos da Ordem dos Advogados do Brasil de Minas Gerais (OAB/MG). Advogada. E-mail: karinbhering@gmail.com

\begin{abstract}
Objectives: The human being is living in times when extreme individuality and self feelings are overvalued and praised. Each day self promotion is increasingly sought by the individual. Through Instagram, for example, pictures are posted in order to achieve a greater number of likes. Through the social media, love, desire, happiness and individual feelings are publicly shown. In the new capitalistic wealth accumulation logic, corporations like Facebook, Google, among others, are constantly capturing such individual moments to be traded off for profits, and no one is noticing, or if someone is noticing, is not aware that is all constantly watched. This article intends to review how these new controlling technologies can be prejudicial to workers.
\end{abstract}

Methodology: The methodology used is dialogical deductive, through bibliographic research for construction and development of research, having as main thinkers Michel Focault, Zygmunt Bauman and Jeremy Bentham.

Results: One of the conclusions of the author is that in a surveillance environment by the employer, there will only be a power relation, when the employee is able to act as an active person - both in accepting and subverting his role - before such surveillance. In the contrary, it will not be a power relation but rather a mere coercion relation. And if there is not a power exercise, there is not an exercise of liberty either.

Contributions: The article seeks the reader's attention on the extraction of surplus value, which today seems not only to be the surplus of the workforce, but also the happiness and subjectivity of the worker. As a contribution, the author highlights the new invasive surveillance of the employer as well as the shadow side of the marketing and unnecessary consumption to enrich companies to the detriment of individuals. The employer, seeking greater productivity and profit and due to the advancement of new technologies, controls his worker, either inside or outside the workplace. The worker, therefore, without the right to disconnect, is constantly monitored during the workday and also in his moments of rest. 
KEYWORDS: Controlling of the work force; discipline; social media; private lives; The Bentham system; Labor law.

\section{RESUMO}

Objetivos: Vivem-se tempos de valorização da subjetividade do eu. Cada dia mais busca-se uma autoafirmação. Por meio do Instagram, por exemplo, fotos são postadas com a pretensão de ganhar os famosos likes. Através das redes sociais, demonstram-se afetos, desejos, prazeres, felicidades, subjetividades. Paralelamente, na nova lógica de acumulação capitalista, empresas como Instagram, Facebook, Google, entre outras, estão constantemente capturando essas subjetividades em troca de lucro e não se percebe, ou se percebe e não se toma consciência, que todos são constantemente vigiados. Este artigo pretende analisar como esse controle acentuado por essa nova lógica de acumulação pode prejudicar o trabalhador.

Metodologia: A metodologia utilizada é dedutiva dialógica, por meio de pesquisa bibliográfica para construção e desenvolvimento da pesquisa, tomando-se como principais pensadores Michel Focault, Zygmunt Bauman e Jeremy Bentham.

Resultados: Uma das conclusões do autor é que, em um ambiente de vigilância por parte do empregador, haverá apenas uma relação de poder, quando o empregado puder atuar como uma pessoa ativa - tanto na aceitação quanto na subversão de seu papel - antes dessa vigilância. Pelo contrário, não será uma relação de poder, mas uma mera relação de coerção. E se não há um exercício de poder, também não há um exercício de liberdade.

Contribuições: $O$ artigo busca a atenção do leitor sobre a extração da mais valia, que, hoje, não parecer ser apenas o excedente da força de trabalho, mas também a felicidade e a subjetividade do trabalhador. Como contribuição, o autor destaca a nova vigilância invasiva do empregador, bem como o lado sombrio do marketing e do consumo desnecessário para enriquecer as empresas em detrimento das pessoas. $O$ empregador, buscando maior produtividade e lucro e devido ao avanço das novas tecnologias, controla seu trabalhador, seja dentro do trabalho ou fora dele. O trabalhador, portanto, sem direito à desconexão, encontra-se constantemente monitorado durante a jornada de trabalho e também em seus momentos de descanso.

PALAVRAS-CHAVE: Vigilância; controle; disciplina; redes sociais; vida privada; Panóptico de Bentham; Direito do Trabalho. 


\section{INTRODUCTION}

Nowadays, where the subjectiveness of everything is over emphasized, as a means to reach a self determination. Through Instagram, for example, pictures are posted with the intention of reaching a greater number of the famous "likes"'. By means of the social media, the subjectiveness aspects of things are demonstrated. At the same time, within the new capitalistic accumulation logic, companies like Instrgram, Facebook, Google among others, are constantly capturing such a subjectiveness in exchange for profit and one does not notice, or if one notices, one does not acknowledge that everyone is being constantly watched.

Due to technology developments, we now live in the information era. Everyone is constantly connected, be it by means of the internet or through some type of social media, such as Instagram or Facebook. In a certain way technology is a great paradox: at the same time that it brings us freedom - we have access to all types of information in a speed never imaged before, we can get in contact with any person, at any time, in any place of the world - she imprisons - make everyone increasingly addicted, controlled by, watched and more alienated, being transformed into "puppets" of a system that gathers their data all the time.

Another great paradox is how one's life in the work place and his or her private life are both mixed and indistinguishable, when they are, or should be, separate. In today's world, where there are no more ways to disconnect yourself, the internet, the social media, the electronic devices, as well as the computers and cell phones could be considered, as if they were, parts of our bodies - as are our arms, legs and heads. In the typical capitalism, the worker sells his workforce to a third party in exchange of a

\footnotetext{
1 The application has announced that it will conduct tests hiding the number of likes, so that content seeking is stimulated, not statistics. "According to Instagram, such modification started this Wednesday and it will remove not only the number of likes, but also the number of video visualizations. 'We do not want that people feel that they are in a competition inside Instagram, and we expect to understand if such a change could help people to focus less in the number of likes, and more in telling their own stories, the company informed." Available at: <https://www.hojeemdia.com.br/horizontes/instagramtesta-deixar-de-exibir-curtidas-em-postagens-entenda-o-porqu\%C3\%AA-1.728300> Access in 19/07/2019.
} 
compensation and the capital, through the exceeding labor force, extracts what Marx calls the surplus added value of his labor.

In the new accumulation logic, the capital does not necessarily needs the exceeding labor force in order to obtain a profit. Through the extraction of the data of its users a new extremely profitable and competing market has been discovered. The users, on the other hand, transfer their data, their private information, without knowing to whom, or to where such a data is going, or how this could affect their lives.

And such is the way that the worker, controlled on systematic way, within or out of the workplace, transfers not only his or her subjectiveness, as well the corresponding privacy, together with the personal right to be disconnected, besides leisure time and maybe even his or her happiness.

This excessive monitoring ends with the uncertainty of life, a human characteristic, since, after all humans are not machines.

This present work, therefore, intends to analyze how the deep control of the new accumulation logic is delimiting and can harm the worker and suggests, as we will see, that a change in the action and in the awareness of the problem in working relations, should concentrate on the analyzes of the question on the workers point of view, as pointed out by Michel Lowy ${ }^{2}$, and which could reach possible increase on the limits for the control and surveillance of works in the present times.

\section{NEW ACCUMULATION LOGIC: THE SURVEILANCE CAPITALISM}

In Ricardo Antunes words "we are living the primitive accumulation phase of the digital era" (ANTUNES, 2019). Analyzing this subject matter, Shoshana Zuboff defines this new accumulation logic starting in the big data and says that "it is, above

\footnotetext{
2 "The analyzes of Lowy still considers that a proletarian vision can and should be able to incorporate the partial truths produced by the limited or inferior sciences, and this not necessarily takes one to an eclecticism. His conclusion certifies that the proletariat, to the extent that they search for the access to truth, is a more critic revolutionary class, but such does not push the author to sufficiently guaranteeing the knowledge of the social truth." Available at: < https://journals.openedition.org/confins/6544?lang=pt $>$. Access in 19/07/2019.
} 
all, a fundamental component of a new accumulation logic, profoundly intentional and with important consequences", which the author denominates "surveillance capitalism" (ZUBOFF, 2018, p. 18). For her, "this new form of information capitalism looks for a way to forcast and modify the human behavior as a way to produce market control recipes" (ZUBOFF, 2018, p.18).

Such a thesis analyzes Google which was "the pioneer of the big data and with such strength was also the pioneer in the logic of the wider accumulation (...) of a surveillance capitalism, from which the big data is a condition as well as an expression". Such accumulation logic is also shared by companies as Facebook, starups and applications (ZUBOFF, 2018, p. 24-25).

Zuboff explains that Google:

[...] was a clear example of the individual empowerment in the demands for a more productive life. But, as the pressures for profit develop, Google leaders were worried about the effects that paid service models could have on the growth of the number of users. They then decided for an advertisement model. This new approach was dependent on the data acquisition from users as a raw material for the analyzes and production of algorithms that could sell and divide advertisement by means of an exclusive auction model, with greater precision and success. (ZUBOFF, 2018, p. 32)

One example of this is the Google street view, launched in 2007. "German Authorities found out that, among other problems, the street view cars were equipped with scanners activated in order to extract data from social media through private wireless networks" (K.J.; C.C., 2014, apud Zuboff, 2018, p. 28-29). In a lawsuit filed against Google, it was ruled that "the company participated in the non authorized data gathering from private wireless networks, including the data from private wi-fi from residential area users [...]" and "that Google intentionally intercepted data with commercial purposes and that engineers and supervisors from that company revised the source-code and documents related to the such project." (EPIC, 2014, apud ZUBOFF, 2018, p. 28-29). Google settled the case in a US\$7 million dollar agreement which, for a company of its size, does not mean anything (ZUBOFF, 2018, p. 29).

Therefore, the "modus operandi of Google consists in making incursions in private and protected territories until some type of resistance is found", (ZUBOFF, 
2018 , p. 30). For the company "innovation is ahead of everything and she resists asking for permission" (D. Streitfeld, 2018, apud ZUBOFF, 2018, p. 30). Accordingly she "exhausts her adversaries in court or eventually agrees in paying penalties and fines which represent an irrelevant investment amount for a significant return" (ZUBOFF, 2018, p. 30). This practice is called by some as being an "infrastructure imperialism" (S. 2011, apud ZUBOFF, 2018, p. 30).

According to this new accumulation logic adopted by companies such as Google "[...] populations are no longer necessary as a source for clients or employees. The advertisers are their clients, together with other intermediaries who buy their data analyzes" (ZUBOFF, 2018, p. 37).

Such companies do not need a high number of workers in order to operate and function. This is so true that Google, until 2015, had only about 48 thousand workers and "is known for having thousands of candidates for each of its job opening, in contrast to General Motors that, at the highest of its powers, in 1953, was the greatest private employer in the world" (ZUBOFF, 2018, p. 37-38).

In the own words of Varian, Google's Chief Economist: "Since transactions are now sorted by the computer, we can observe behaviors that we could not observe before and write contracts taking in consideration such behaviors" (H.R. apud ZUBOFF, 2018, p. 41). According to him:

[...] if someone stops paying his car's monthly installments, the creditor can "instruct the vehicle security monitoring device and stop the car's ignition system and get the signal of the car's location in order for it to be recovered". The insurance companies, he suggests, can count with similar security monitoring systems in order to verify if the their clients are safe driving and, therefore, determine if they should keep the client or pay him back the insurance premium. He also suggests that remote local private agents can be hired to execute such tasks and use their smartphone data - geo location, time register, photos - in order to "show evidence" that they really fulfilled their contract obligations. (O. E., 1885, apud ZUBOFF, 2018, p. 41).

But what Google's Chief Economist seems not to have paid attention to is that his vision "about the uses of the computer mediated transactions is that they get rid of the uncertainty element of the contract, as well as the necessity of the possibility of a trust development" (ZUBOFF, 2018, p. 42). 
Another way to say this is that legal contracts are moved from the social phenomenon circle and reconceived as a machinery procedure. The consensual participation from which its authority is derived and legitimized, together with the corresponding free will and the reciprocal rights and obligations, are substituted by the equivalent to the electronic tag of a prisoner. (ZUBOFF, 2018, p. 42).

About the work place environment, one comparison is necessary, since that the excessive monitoring also breaks the uncertainty of the legal contract, as well as with the possibility of a trust development, since, after all, employees are not machines, but humans. As a matter of fact, for Hannah Arendt "the human fallibility in the fulfillment of a contract is the price of liberty. The impossibility of a perfect control within a specific community of equals is the consequence of plurality and reality [...]" (ARENDT, 1998, apud ZUBOFF, 2018, p. 43).

For Zuboff, this new world architecture is called Big Other:

Instead of allowing new contractual forms, this arrangements describe the birth moment of the new universal architecture that exists between nature and God, which I have called Big Other. This new architecture, is consisted of an ubiquitous institutional network regime that registers, modifies and commercializes the everyday experience, from the simple use of a domestic electronic device, until the very human body, the thought communication, all with its main purpose to establish new ways of monetizing and reaching profit. The Big Other is the sovereign power of a near future that destroys the freedom reached by the rule of law. It is a new regime of independent facts, and independently controlled, that surpasses the necessity of contracts, of governance and the dynamism of a market democracy. (ZUBOFF, 2018, p. 43-44).

According to the author "the Big Other exists in the absence of a legitimate authority and it is, in great part, free from detection or sanctions. In this sense the Big Other can be described as an automated strike from above: not a coup d'État ${ }^{3}$, but rather a coup des gens" (ZUBOFF, 2018, p. 49).

For her, not even the panoptic of Bentham is able to be compared with such a new architecture. This is why, at the panoptism of Bentham, the control could be extinct

3 "State coup" in french.
4 "People coup" in french.

nch. 
at the moment that such a person would leave that physical place and, according to such an author, in the new architecture, there is no such possibility.

\begin{abstract}
Even the panoptic of the Bentham $\{\ldots\}$ is prosaic if compared with this new architecture. The panoptic was a physical project in which a single observation point was privileged. The anticipated conformity that it induced would require the production of specific behaviors from the ones inside the panoptic, but such a behavior could be left aside once such a person had left this physical place. In the 1980's, the panoptic was an adequate metaphor for hierarchic spaces in the work place. In a world organized after the Varian assumptions, the habitat inside and out of the human body is saturated with data and produce radical distributed opportunities for observation, interpretation, communication, influence, prediction and, in last instance, the change of the whole action. On the contrary of the central power of the mass society, there is no scape in relation to Big Other. There is no place to be where the Other is not either. (ZUBOFF, 2018, p. 43-44).
\end{abstract}

The same conclusion is reached in relation to the work place environment. Due to this new architecture, the worker can no longer leave from the constant surveillance of his employer. This is so since today, even when one is out of the work place, it is possible such a control - through Internet, Whatsapp, Instragram, Facebook and even by means of specific applications (digital control done by companies like Uber).

The technological development has contributed to the birth of an algorithm subordination in which the control is not done by hour any longer, but by applications (TEODORO, et al, 2017, p. 18). And the reason for this is the following:

The new technologies are giving birth to new subordination forms, as has been observed by the French jurist Alain Supiot. And exactly because such forms are disguised, they become more severe and effective than the ones enforced directly by the immediate local boss, at the "factory floor", when the employee was subject only to the starring eyes of his superiors, within his working hours. (DE CASTILHO, 2019).

In a certain way, technology is a great paradox: at the same time that it liberates, since it allows the access to all and every type of information, at a never ever imaged speed, enabling the contact with anyone, at any time, at anywhere in the world - she imprisons - since, when one tastes a forbidden fruit, it becomes impossible to live without it (ZUBOFF, 2018, p. 50) so people are becoming even more dependent, 
more controlled, more surveilled, more alienated, and becoming therefore "puppets" of a system that gathers their data all the time.

Zuboff explains that "[...] when Facebook access temporarily failed for technical problems in some cities of the united States during a few hours in the summer of 2014, many [...] people called the local 911 emergency services" (Los Angeles Times, 2014, apud ZUBOFF, 2018, p. 50-51). Moreover, according to such an author:

This social dependence is at the heart of the surveillance project. Strongly felt necessities are considered as essential to a more effective life and therefore are against resisting to the surveillance project. This conflict produces a type of psico torpor that get people to be accustomed to being tracked, analyzed, mined, and modified - or make them predisposed to rationalize the situation with a resigned cynicism. (C. J. et al, 2010, apud ZUBOFF, 2018, p. 51)

\section{THE PANOPTIC OF BENTHAM, THE DISCIPLINARY SOCIETY OF FOUCOULT AND THE SOCIETY CONTROL OF DELEUZE}

The Panoptic of Jeremy Bentham was the place in which the apartments of the prisoners were located in a circle, while the apartment of the inspector was located in the center of a circular building. The prisoner, therefore, was constantly closely watched by the eyes of the inspector (NUNES, 2018, p. 164).

The idea was that "the more often the people who were to be closely watched were actually within the sight of the inspectors, the more perfect the objective of such a task will be reached". For Bentham the "ideal perfection, if that was the objective, would require that each person would be in such a condition, during every moment of time". (BENTHAM, 2008, p. 20).

According to Bentham, the panoptic was applicable to "any type of business, in which any type of people needed to be under inspection" (BETHAM, 2008, p. 15).

It is not important how different, or even now opposite, may the purpose be: be it to punish what can not be corrected, to finish the insane, to treat the addicted, to lock up the suspect, to give work to the unemployed, to help the unassisted, to heal the sick, to educate the willing ones who are available in any type of industry, or to train the rising race in the path of education, in one 
word, be it applied to the purposes of perpetual imprisonment in the death chamber, or confinement prisons before the legal trial, or penitentiary facilities, or correction houses, or working houses, or manufacturing houses, or mental institutions, or hospitals, or schools. (BENTHAM, 2008, p. 19-20).

It was due to the analyzes of the shape of power exercised in the panopticism of Bentham that Foucault later conceived his three instruments: the hierarchy surveillance, the penalization enforcement and the combination of these two first instruments.

\begin{abstract}
The exam combines the existing hierarchy technique and the penalization enforcement of the regulation. It is a regulating control, a surveillance that allows to qualify, to classify and to punish. It establishes a visibility over the individuals through which they are differentiated and sanctioned. This is why in all the disciplinary devices the exam is highly ritualized. In them one can unite the ceremonial power and the experience form, the demonstration of power and the establishment of truth. In the heart of the disciplinary procedures, he demonstrates how the ones perceived as objects are submissive as well as the objectivation of the subject. The superposition of the power relations and the knowledge relations resumes all its visible bright. (FOUCAULT, 1987, p. 154).
\end{abstract}

Through the combination of these instruments "it possible to directly and significantly influence the individuals without having to use the physical force." This way, it is possible to "mold and convert an individual from the potential enemy condition to an individual that is useful to the society in which he is lives" (GUANDALINI; TOMIZAWA, 2013, p. 28).

Michel Foucault, when analyzing the architecture of the panoptic of Jeremy Bentham, in which he inspired himself, says that it has "the effect of inducing in the detained person a conscious and permanent state of visibility, that guarantees the automatic function of the power". An architecture capable of "creating and sustaining a power relation which is independent of the one that exercises it". Foucault also states that in relation to the one who is the object of the surveillance, the "essential is that he knows he is being watched [...]" since that "he does not have the necessity of actually being watched". Besides that he "is seen, but does not see; is the object of an information, never a subject of communication". According to the author, through panoptism, "a mechanical and real subjection is born from a fictitious relation". For 
Foucault, the panoptic has as its "negative effect - to miss these compact, lively, and vibrant masses, that were found at these finalizing places [...]" (FOUCAULT, 1987, p. 166-167). The author also explains that "the panoptic can be used as an experience making machine, to modify behavior, to train or retrain the individuals." 1987 , p. 168). A power mechanism in which "its force is never to intervene, and it is to be exercised in a spontaneous manner, in a soundless fashion, it is a mechanism with riddle effects" (FOUCAULT, 1987, p. 170).

Foucault says that "the panopticism is the general principle of a new 'political anatomy', whose object and purpose are sovereign relations but rather the disciplinary relations". (FOCAULT, 1987, p. 172).

The discipline rules, according to Foucault, "act, in a ever extending manner, as techniques that create useful individuals" (FOUCALT, 1987, p. 174). According to the author:

\begin{abstract}
The discipline rules, organizing the 'cells', the 'places' and the 'lines' create complex spaces: at the same time that they are architectural, functional and hierarchized. They are spaces that make the fixation and allow the circulation; they cut individual segments and establish operational liaisons; set up places and point out values; guarantees the obedience of individuals, but also a better economical use of time and gestures (...). The first of the great operations of the disciplinary rules is, then, the construction of a 'living staff' that transforms the confused, useless and dangerous multitudes, into an organized plurality [...] (FOUCAULT, 1987, p. 126).
\end{abstract}

The authors De Souza and Muçouçah sustain that "[...] the 'living staff' was, at the same time, a power technique and a knowledge procedure, whose intention was to dominate the diversity, enforcing an order". (DE SOUZA; MUÇOUÇAH, 2018, p. 2).

\footnotetext{
${ }^{5}$ About the behavior molding, a suggestion is made in relation to the Pavlov experiment on the classic inducement training, which consists of the association of a initially neutral stimulus with a significant one. According to the experiment, the dog that initially salivated to food in its mouth, can change to salivate to a bell ringing by means of inducement training. "A possible explanation for this is that a 'tasting' 'stimulus' (food) brings out a tasting answer that self stimulates the dog. This self stimulus brings out the dog's salivation." After such inducement training - when the bell rings before the feeding procedure - the audible stimulus (bell), which was originally neutral, starts to bring out a salivating response. That is, after the salivation stimulus is associated to the audible stimulus, this last one that was neutral, starts to bring out tasting responses after a certain period of inducement training. Available at: < http://www.scielo.br/pdf/\%0D/ptp/v18n2/a03v18n2.pdf > Access in 24/07/2019.
} 
The discipline rules, explains Foucault, "are techniques used for the assurance of the organized human multitudes" (FOUCAULT, 1987, p. 179).

\begin{abstract}
But the essence of such disciplinary rules is that they try to define, in relation to the human multitudes, a tactic of power that answers to three criteria: to make the exercise of power the least costly possible (economically, for the amount of corresponding expenses; politically, for its discretion, its weak exteriorizantion, its relatively invisibility, and the little resistance that it demandes); make that the effects of such a social power are taken to its maximum intensity levels, and extended to as far as possible, without failure, or an empty space; to link, finally this "economic" power growth and the results of its interior devices in which it operates (be it pedagogic, military, industrials or medical devices), or, in conclusion, to increase, at the same time, the softness and the utility of all the system elements. (FOUCAULT, 1987, p. 179180).
\end{abstract}

The disciplinary society, according to Foucault, is "a power mechanism that allows time and work to be extracted from the human body, more than goods or wealth. It is a type of power that one exercises continuously by the surveillance and not by a discontinuous way through tax systems or severe obligations [...]" (FOUCAULT, 1999, p. 42). This extraction of the "maximum of time and strength" is due to the fact that the disciplines require themselves to "make each single element of utility of the multitude to grow, but by means that are more quickly and less costly, in another words, using the multitude itself as an instrument of such a growth.[...]"(FOUCAULT, 1987, p. 181). With the confinement crisis, the disciplinary society is substituted by the control society (NUNES, 2018, p. 166). According to Gilles Deleuze:

[...] the controlling societies operate through three types of machines, computers and other technological devices, whose the passive danger is the interference, and the assets are piracy and virus. It is not a technological evolution without being, even in a deeper aspect, a capitalism mutation. It is a mutation that is well known and that can be summarized as follows: the XIX century capitalism is a concentration one, for the production and the property. As such it elects the factory as a means of confinement, the capitalist being the owner of the means of production, but also the owner of the other spaces conceived by analogy (the workers family home, the school) [...] It is a capitalism of over production. It does not buy raw materials any longer, nor it sells finished goods: buys finished goods, or puts together specific parts. What it really wants to sell are services, and what it wants to buy are stocks. It is no longer a capitalism aimed at production, but at the product, that is, aimed to selling and to the market. For that reason it is essentially dispersive, and the factory gave its place to the company. [...] The seizing of markets are carried 
out by control taking, and not anymore by discipline formation, by the setting of quotation than by cost reducing, by product transforming than by product specializing [...]. Marketing is now a social controlling instrument, and the way of our imprudent masters. Such system is a short time one, with a quick rotation, but also an unlimited and continuous one, where the discipline had a long, discontinued and indefinite duration. (DELEUZE, 1992, p. 3).

In relation to the work environment, "the business organization system that existed before was based on direct surveillance, with a primary and strong hierarchy" (DE SOUZA; MUÇOUÇAH, 2018, p. 6).

Nowadays, with the technological development, the surveillance is electronically carried out "inside a organizational context by various types of technological devices like cameras, microphones or computers [...]" (DE SOUZA; MUÇOUÇAH, 2018, p. 7), as well as via Internet, Whatsapp, Instagram, Facebook and even applications (digital control carried out by companies such as Uber), in a scenery where a small number of people can make the surveillance of many, in a spectator society (MATHIESEN, 1998, apud GUANDALINI; TOMIZAWA, 2013, p. 37).

This work relations monitoring has its purpose in the conflict neutralization, the labor force domination and a greater productivity and profits, for example.

According to José Eduardo de Resende Chaves Junior, in the control society:

\begin{abstract}
The employment power is detached from the physical discipline and from the length of labor, and linked to the control of the soul and to marketing. The control system is not interested in one's confinement within the factory, during fixed certain working hours, within a linear discipline, of a stable working legal contract, but rather, actually, to a temporary link, in the cloud, post contractual, post material. A virtual reality contract is born. (CHAVES JÚNIOR, 2017).
\end{abstract}

With the new accumulation logic "[...] a fictious forth the merchandize is born as a XXI century dynamic dominant characteristic. The reality itself is going through the same type of fictitious metarmorphosis that people, nature and trade are going through" (ZUBOFF, 2018, p. 56).

The "reality" is now dominated by mercantile procedures and monetization of things, and therefore, a new "behavior" is born. The data, about the behavior of bodies, minds and the things, occupies important places in the dynamic universal compilation, in real time, of intelligent objects in the middle of an 
infinite global domain of interconnected things. This new phenomenon creates the possibility of modifying the behavior of people and things having, as an objective, profit and control. In the surveillance capitalism logic, there are no individuals, but only a world organism and all the small elements in its interior. (ZUBOFF, 2018, p. 56).

In relation to the working environment, such control invades "the leisure and resting time, $[\ldots]$ violating the intimacy and the private life of the worker, by means of telematics and electronic tools, that are more advanced each time, being compared to the panoptic surveillance model, and that are, however, applied in a more subtle way [...]" (NUNES, 2018, p. 168).

\section{THE EXTRACT OF A MODERN SURPLUS ADDED VALUE: THE SUBJECTIVENESS AND HAPPINESS}

In the modern solid capitalism (BAUMAN, 2001), the workers sell their labor force to a third party in exchange for a rendered service, and the capital, through the exceeding labor force, extracts what Marx calls the surplus added value.

In the new accumulation logic, typical of the liquid modernity (BAUMAN, 2001), or in the later one (BECK, 2011) the capital starts to make his own the production means, not necessarily the material goods. The capitalistic production system refines itself in a way in order to extract its profit, and starts a new production model, in a disruptive movement, by means of the data extraction from its users. These ones sell their data, eventually, without knowing really to whom, or to where such data is going, and how this could effect their lives.

And this is the way that the worker, being constantly controlled, within and outside the his work, sells not only his data, but also his subjectiveness, his privacy, his right to be disconnected, his leisure time and, therefore, his happiness.

High well being can generate greater productivity. Therefore, a happy worker can be more productive. A Portuguese conducted study, that had trials with " 272 collaborators from 132 organizations" (REGO, 2009, p. 215), has concluded that: 
[...] the well being in work place explains the significant change in the self reported individual performance. The workers with high well being in the work place describe themselves as relevant achievers. The enthusiasm and vigor are both the best dimension of the work well being. It is probable that the more optimistic and enthusiastic the workers, the more dedicated to the word they are, and therefore they apply their energy and potential in the fulfillment of their tasks, actively search for problem solving, take all the opportunities, and be more intensive in overcoming obstacles, and establish more agreeable social relations and therefore can more efficiently exercise their duties and responsibilities. (REGO, 2009, p. 226).

The psico burden seems to be the consequence of the new work forms, shaped by a flexible accumulation era, in which there is a high productivity requirement and a accelerated work rhythm. Due to the deep subordination to technology and to surveillance methods, resting pauses are eliminated. (VAPIANA et al, 2018).

The employer, therefore, through the excessive control tries to reach a greater productivity from his worker, as well as a higher profit but, as he eliminates the unproductive time of the employee, he does not notice that he turns him more subject to becoming mentally or even physically ill, making his employee, paradoxically, less productive.

According to Seligmann-Silva, the excessive work, diminishing work pauses, can cause many types of psychological hardships and breakdowns. Some of the most common psychological problems mentioned by the author are depression, post traumatic stress (PST), professional burnout, alcohol or drug addiction and paranoid syndromes. (SELIGMANN-SILVA, 2009).

In relation to the "paranoid syndromes" the author explains that "when rigid control and punitive devices and practices are associated, there is a probability increase that the employees feel less quiet and threatened. In such circumstance, it is not rare that persecuting fantasies and ideas are expressed, that is, ideas of being chased." The author also states that "the greater the communications barriers and the isolation of the employees are, greater will also be the possibility that these manifestations are developed". (SELIGMANN-SILVA, 2009). He also says: 
control and the appearance of insecurity feelings. When there is a visible supervisor or chief, with whom it is possible to speak to or discuss, the situation is less preoccupying than when the surveillance is hidden, and done by means not known to the employee. (SELIGMANN-SILVA, 2009).

Just like Google, Instagram, Facebook etc - that constantly capture the subjectiveness of their users in exchange for profit - companies also learned how to capture the subjectiveness of their employees. In this "new speech in order to dissimulate the class structure and to conquer the body and soul of the their workers: the employees become collaborators" (COUTINHO, 2019). And, therefore, "one can say that the work can steel even more the happiness, invade even more the subjectiveness and - in the limit - can eliminate the viability of a possible work disconnection" (VIANA; TEODORO, 2017, p. 313).

The worker, disposed of his own subjetiveness experiences a fake autonomy and a true "Supervisor Syndrome" 6 and:

\begin{abstract}
As in all syndromes, this one also generates bad consequences. The first one is empting the content of Labor law, since that when the workers do not recognize themselves as members of a wording class, they lose the feeling of belonging, in the name of a fallacious dream of being the "boss" and to make more money, which diminishes the enforcement capability of the labor regulation and makes weaker this specialized law field. The second effect consists in the worker itself turn his back against the Labor Law, since such an employee, through his self and egoistic vision, observes only whatever is good for himself in the short term, in an immediate moment, without noticing himself as a class member, whose fight needs his participation. (TEODORO, 2015).
\end{abstract}

Therefore, what we have observed is that this new production model enables a greater productivity for the employer, through the inside and outside control of the work - subtracting the workers subjectiveness and his resting and leisure moments

\footnotetext{
6 "The employer syndrome" - in an analogy to the Stockholm syndrome - arises during a valid contractual relation - in which the employee internalizes the idea that he "is" employed, but it "will" not be for a long time -, or in the situation that the employee considers more "advantageous" to his equity to ask for being laid off and to start his own company - as a limited liability company, in many instances - becoming therefore his own "employer" and the employer of others - his future employees; or even through the internal acceptance of the School of Life ideology, by which "one who loves what he makes" ends up turning himself into a more gentle worker who is easily submitted to precarious working conditions (TEODORO, 2015).
} 
with which he obtains his happiness - and what one really realizes is that, in reality, there is a "hipperconnection to work" and an "unmeasured exploitation", as explains the author José Eduardo de Resende Chaves Junior:

In the control system, the labor with precarious working legal links can be easily organized, given that such legal links are continuous, plugged on line, virtual. Heterogenic connections are established, without identity, similarity or homogeneity [...] The English zero hour work is the endless work. It is the hipperconnection to work. Zero that touches the infinite. The control, by means of the electronic bench, is checked to the millimeter, but it is not possible to measure the exploration. (CHAVES JÚNIOR, 2017).

\section{CONCLUSION}

According to the author Milton Santos: "since this disordered order is global one, belonging to the present global productive process, such an order has no limits; but it has no limits because it has no purposes and, in this sense, no regulation is possible, since it is not wanted." (SANTOS, 2001, p. 86).

A great effort is needed by all the law related agents, as well as a change in the perspective and in the ethical horizons when labor relations are studied - so that such relations are actually power relations - by its own participants, so that limits are applied to this capitalistic accumulation system, which has this excess surveillance and this control of the society, be it in relation to the users or the workers.

Power relations, according to Foucault:

A power relation, in the contrary, is carried out by two elements that are indispensable in order to really be a power relation: that "the other" (the one over whom it is exercised) is recognized and kept until the end as the subject of the action; and that, before the power relation, it opens itself to all types of responses, effect reactions, and possible inventions. The functioning of the power relations, it is clear, it is not an exclusivity of the use of violence, more than the acquisition of consents; no power exercise can, without doubt, dismiss one or the other and frequently the both of them at the same time. [...] There is not a power relation where the determinations are saturated - the slavery is not a power relation, since the man is chained (it is therefore a physical coercion relation) - but only when one is able to move and, in the limit, escape. (FOUCALT, 1995, p. 243-244) 
Besides that, as explains Pez (2010, p. 11), according to Foucault, the exercise of liberty "is a exercise of power, in another words, there is not power exercise where there is no possibility of action and [...] there is no exercise of liberty where there is no exercise of power."

Hence, in a surveillance environment by the employer, there will only be a power relation, when the employee is able to act as an active person - both in accepting and subverting the his role - before such surveillance. In the contrary, it will not be a power relation but rather a mere coercion relation. And if there is not a power exercise, there is not a exercise of liberty either.

In spite of the fact that there can be leisure moments, since labor is in the necessity side of life, there can be no liberty. This is because, on the contrary of the civil contract theory, the labor contract has as it core and essential characteristic, the directive power, and this is why, "in a different way than the civil contract, in the labor environment the liberty can hide its true necessity" (VIANA; TEODORO, 2017, p. 315). And it is inside the necessity aspect of it that the labor contract is nearer to the consumer contract than to the civil contract. This is so because "the very offering and consuming of products and services, indispensable to a consumer dignifying life, within the capitalistic standards, makes such a contract to be a consequence and a subordination result of the consumer to his necessities, more than his wish and desire results" (VIANA; TEODORO, 2017, p. 319).

Such is also the understanding of Bauman for whom "the liberty of the consumer means a life direction for the goods approved by the market, which impedes a crucial freedom: of freeing one from the market, freedom which means everything but the choice of standard commercial goods" (BAUMAN, 1999, p. 277). Another important aspect is that:

[...] if consuming is based on a presumption of income, such a presumption is in the labor. This way, capitalism, which has in it the logic of a creative destruction, ended up by molding, step by step - throughout the time - the consumer profile and, before them, the workers themselves, transferring the labor to the necessity terrain, if not to the human own existence. (VIANA; TEODORO, 2017, p. 320). 
And this is why the "necessity to consume, as well as the necessity to work to another person, are faces of the same coin [...]", so that both of them are, in essence, "present in capitalistic own logic. As the employee are subtracted from their means of production, the system has turned them, necessarily, dependent on the work and on the consuming of goods" (VIANA; TEODORO, 2017, p. 320).

All this is the consequence of a "command" and a "discipline" that "are incorporated so strongly in our hearts and minds that work time registering or to follow the supervisor's orders are almost like going to the bathroom, to change clothes, to light up a cigarette or to have pasta for lunch". (VIANA; TEODORO, 2017, p. 322).

Therefore what one reckons is that if there is a "do" on behalf of the worker, such action is only to fulfill rules, to accept the required and enforced control, without thinking, without questioning. But would such "do", in this case, mean liberty?

The answer continues to be no. Since, if one is only a follower of rules, one is not even willingly acting, for the lack of being able to question oneself. So it is necessary to rethink the paths so that the worker's acting capacity, in a surveillance environment, and subjected to a controlled behavior, is able to establish a power relation and not a coercion relation.

Moreover, "even though it is rather common that in certain surveillance environments one tries to resist to being watched, in the majority of places the surveillance has become so wide spread that most people accept it without questioning". (E. et al, 2010, apud LYON, 2018, p. 159).

According to the author David Lyon (2018) "such acceptance can be explained by means of common place factors: familiarity, fear, and fun" (LYON, 2014, apud LYON 2018, p. 159).

In relation "[...] to the first, familiarity, surveillance has become an aspect of life that is a given fact, starting with the supermarket fidelity cards until [...] public and private place cameras and security airport routines [...]" (D.; W., 2009, apud, LYON 2018, p. 159).

Now about the fear, the author explains "that it has become more relevant after the $9 / 11$ attacks, and it is evident that the reported desire for surveillance measures is 
related to the generation of fear related uncertainty and the media amplified exploration of it" (LYON, apud, LYON, 2018, p. 160).

Relation is made, at this point, to the thesis of Ulrich Beck about the "risk society". According to this author, in the "late modernity, the social production of wealth is systematically followed by the social risk production" (BECK, 2011, p. 23). Beck (2011) warns that we have not yet emerged in a risk society, but the problems that worry us are not only the ones related only to questions involving the lack of goods and distributing conflicts.

In the "risk society" all the created risks in a specific place can directly impact all globe, even in a unequal way. The risks, sooner or later, end up reaching those who were responsible for the production or that profited from them. They have a boomerang effect (BECK, 2011, p. 44). This is, according to the author, because "the fish that comes from contaminated waters is a threat not only to the people that eat them, but also, because of that, for the ones that live from them" (BECK, 2011, p. 47).

This way, threatened situations, the sustainability of life is limited and directly related to the knowledge production. As states the author:

[...] the sociology and the political theory of the risk society are, on its core, knowledge sociology; not science sociology, but precisely the sociology of all amalgamations, incorporations and cognitive actors, in its conflicted absorptions and mutual confronting engagements, its fundaments, its intents, its mistakes, its irrationalities, its truths, its impossibilities, the knowledge that they allege possessing. (BECK, 2011, p. 66)

In this state of knowledge, the threats, not before known or ignored, become revealing, so that, according to Beck (2011, p. 67) it is the end of its latency. Even so, however, if the threats were increased, and therefore became more noticeable, it is still a doubt, or if, actually, the perception of it, is what has been deepened.

In a certain extent, the perception of such threats may have been increased due to technological and information advances, as it is the case of the media amplified fear of the $9 / 11$ attacks. 
Beck (2011, p. 67) also sustains that the risks can be manipulated, since they are a "bottomless necessity barrel", that ends up creating not only new necessities, but also entire new markets.

Bauman, when lecturing in his work about the economical effects of fear, states that:

\begin{abstract}
A great amount of commercial capital can be - and have been - accumulated from insecurity and fear. "The advertisement people", for example, comments Stephan Graham, "have systematic explored the general fear of a terrorist catastrophe in order to increase the sales of highly profitable SUVs." These monster almost military gas guzzlers, grossly and wrongfully called "sport utility vehicles", at a certain point reached the $45 \%$ sales market share in the United States, and are being incorporated to the every day life as "defensive capsules. (BAUMAN, 2008, p. 133-134).
\end{abstract}

One can add to these economic effects generated by fear, insecurity and uncertainty, the acceptance of surveillance by many people.

At last, in relation to leisure, this is "also responding by the acquiesce, above all in the social media sector and in the digital devices [...]" and "for many users there are leisure and 'entertainment' aspects in such systems." (LYON, 2018, p. 160).

The author suggests, as a way to develop the debate about a possible solution to this new capitalistic global logic, to turn out our attention to what he calls surveillance culture, since that "[...] the dominant public and the academic speech about surveillance are sustained by the expressions of the State surveillance and surveillance society." For the author, "non of them is appropriate for today, specially because they tend to accentuate the point of view of the surveillance agent $[\ldots]$ and, often they fail to give place to ways like [...] imaginary and surveillance practices that produce complacency, complicity, negotiation or resistance". (LYON, 2018, p. 175). In the same direction, he continues:

Surveillance imaginaries are constructed by the every day involvement with surveillance, as well as articles and popular media, like movies and internet. They include the increasing conscious belief that the modern life is lived under surveillance, that this affects social relations in many ways - for example, "Is my boss going to see my different eccentricities in facebook pages?" -, and that the idea itself of a privacy expectation is debatable and that all other forms, from complacency to confronts, can be proper to respond to 
surveillance. [...] Among the surveillance culture, people negotiate surveillance strategies - for example, very often noticing that the rendering of personal data as trade for self benefits - and adopt such practice as his own, changing them according to the circumstances and starting surveillance forms over themselves and others. (LYON, 2018, p. 161-162)

According to the author "the very idea of culture implies questions such as how to think, to behave, to act, to intervene, and are raised within any social given imaginary" (LYON, 2018, p. 169).

This way, if the imaginary's particular inclination leans to a surveillance mode, at least some type of surveillance ethic will be present. The common subjects should know how to "proceed" in a digital world to the extent that the awareness of the consequences of the generalized and multiple uses of personal data in the modern digital world is growing. [...] (LYON, 2018, p. 169).

Based on this labor relation premise, for these and for other reasons, one can envision in the participants of the labor relations, not only an act but also an awareness rise, from the point of view of the blue color workers (precarious, if one prefers), the possibility to reach not only the solution for the excess of surveillance and control, allowing a greater horizontal effectiveness of the social rights protected by the federal constitution, rescuing the ethic and dignity of the labor relations, so that such relations become power relations again, and are not coercion relations any more, like the work is in these modern and liquid times, or post modern times, paradoxically, rendering the impression that, going backwards, the democratic rule of law is being reduced.

\section{REFERENCES}

ANTUNES. Ricardo. Banca de Doutorado da Pontifícia Universidade Católica. Faculdade de Direito da PUC/MG Unidade Coração Eucarístico. Belo Horizonte. 05/04/19.

BAUMAN, Zigmunt. Modernidade e Ambivalência. Trad. de Marcus Penchel. Rio de Janeiro: Jorge Zahar, 1999. 
2001.

Modernidade líquida. Tradução de Plínio Dentzien. Rio de Janeiro: Zahar,

Medo Líquido. Tradução: Carlos Alberto Medeiros - Rio de Janeiro: Editora Zahar, $1^{a}$ edição, 2008.

BECK, Ulrich. Sociedade de risco - Rumo a uma outra modernidade. Tradução: Sebastião Nascimento - São Paulo: Editora 34, 2ª edição, 2011

BENTHAM, Jeremy. O panóptico. Trad. Guarcia Lopes Louro et al. Belo Horizonte: Autêntica Editora, 2008.

CHAVES JÚNIOR, José Eduardo de Resende. O Direito do Trabalho pós-material: o contrato realidade da <<multidão >> produtora. Pepe Ponto Rede Blog. Disponível em: < https://pepe-ponto-rede.blogspot.com/search?q=0+direito+do+trabalho+pósmaterial\%3A+o+contrato+realidade > Acesso em: 24/07/2019.

COUTINHO, Aldacy Rachid; CIRINO, Samia Moda. TRABALHO, IDENTIDADE E RECONHECIMENTO A" CAPTURA" DA SUBJETIVIDADE DO TRABALHADOR NO CAPITALISMO CONTEMPORÂNEO: UMA ESTRATÉGIA FRUSTADA? Espaço Jurídico Journal of Law [EJJL], v. 19, n. 3, 2019. https://doi.org/10.18593/ejjl.11903

DELEUZE, Gilles. Post-scriptum sobre as sociedades de controle. Trad. Peter Pál Pelbart. Conversações: 1972-1990. Rio de Janeiro. 1992, p. 219-226. Disponível em: $<\quad$ http://www.somaterapia.com.br/wp/wp-content/uploads/2013/05/Deleuze-Postscriptum-sobre-sociedades-de-controle.pdf> Acesso em: 20/07/2019.

DE SOUZA, Aline Lemes; MUÇOUÇAH, Renato de Almeida Oliveira. O panoptico nas relações de trabalho. Disponível em: < http://www.estudosdotrabalho.org/texto/gt6/o_panoptico.pdf> Acesso em: 23/05/2019.

DE CASTILHO, Paulo Cesar Baria. Subordinação por algoritmo nas relações de trabalho. Revolução tecnólogica permite novas formas de controle sobre 0 empregado. Disponível em: < https://www.jota.info/opiniao-eanalise/artigos/subordinacao-por-algoritmo-nas-relacoes-de-trabalho-17062019 > Acesso em: 22/07/2019.

FOUCAULT, Michel. Vigiar e punir: nascimento da prisão. Trad Raquel Ramalhete. Petrópolis: Vozes, 1987. Disponível em: < https://comunicacaodasartesdocorpo.files.wordpress.com/2013/11/foucault-michelvigiar-e-punir.pdf > Acesso em: 20/07/2019.

O sujeito e o poder. Dreyfus, H.; Rabinow, P. Michel Foucault, uma trajetória filosófica. Rio de Janeiro: Forense Universitária, p. 231-249, 1995. Disponível em: < https://s3.amazonaws.com/academia.edu.documents/33146409/o-sujeito-e-o- 
poder.pdf?response-content-

disposition=inline\%3B\%20filename\%3Do_Sujeito_e_o_Poder.pdf\&X-Amz-

Algorithm=AWS4-HMAC-SHA256\&X-Amz-

Credential=AKIAIWOWYYGZ2Y53UL3A\%2F20190617\%2Fus-east-

1\%2Fs3\%2Faws4_request\&X-Amz-Date=20190617T164849Z\&X-Amz-

Expires $=3600 \& X-\overline{A m z}-$ SignedHeaders $=$ host $\& X-A m z-$

Signature $=c 323 f 0 c 5$ defdab20adba06aa1296424155a8a190379123c29fbc2ffdeaf906 7a > Acesso em: 17/06/2019.

Em defesa da sociedade. Trad. Maria Ermantina Galvão. São Paulo:

Martins Fontes, 2005. Disponível em: < http://petdireito.ufsc.br/wpcontent/uploads/2016/05/Foucalut-M.-Em-defesa-da-sociedade.pdf > Acesso em: 20/07/2019.

FRANCO, Daniele. Instagram testa deixar de exibir curtidas em postagens; entenda $O$ porquê. Hoje em Dia. 17 de julho de 2019. Disponível em < https://www.hojeemdia.com.br/horizontes/instagram-testa-deixar-de-exibir-curtidasem-postagens-entenda-o-porqu\%C3\%AA-1.728300 >. Acesso em 28/07/2019.

GUANDALINI, Bruno; TOMIZAWA, Guilherme. 0 mecanismo disciplinar de foucault e o panóptico de bentham na era da informação. 2012. Disponível em: < http://www.opet.com.br/faculdade/revista-anima/pdf/anima9/anima9-2-O-

MECANISMO-DISCIPLINAR-DE-FOUCAULT-E-O-PANOPTICO-DE-BENTHAM-NAERA-DA-INFORMACAO-Bruno-Guandalini-e-Guilherme-Tomizawa.pdf > Acesso em: 19/06/19.

LOPES, Carlos Eduardo; ABIB, José Antônio Damásio. Teoria da percepção no behaviorismo radical. Psicologia: teoria e pesquisa, v. 18, n. 2, p. 129-137, 2002. http://dx.doi.org/10.1590/S0102-37722002000200003

LYON, David. Big Other: Cultura da Vigilância: Envolvimento, Exposição e Ética na Modernidade Digital. In: Fernanda, et al. Tecnopolíticas Da Vigilância: Perspectivas da Margem. São Paulo: Boi Tempo, 2018.

NUNES, Talita Camila Gonçalves. A Precarização no Teletrabalho. Escravidão Tecnológica e Impactos na Saúde Física e Mental do Trabalhador. Belo Horizonte: RTM, 2018.

PEREIRA, Ana Paula Camilo; AREDES, Airton. Michael Löwy, As aventuras de Karl Marx contra o Barão de Münchhausen. São Paulo: Cortez, 220 páginas. Confins. Revue franco-brésilienne de géographie/Revista franco-brasilera de geografia, n. 9, 2010. Disponível em: < https://journals.openedition.org/confins/6544?lang=pt >. Acesso em: 19/07/2019.

PEZ, Tiaraju Dal Pozzo. Pequena análise sobre o sujeito em Foucault: $A$ construção de uma ética possível. www. uel. br/eventos/sepech/arqtxt/resumos- 
anais/TiarajuDPPez. pdf. Acesso em, v. 1, n. 07, p. 2010, 2010. Disponível em: < https://guiaclevelandia.com.br/guia-conteudo/uploads/2017/01/TiarajuDPPez.pdf > Acesso em: 23/05/2019.

REGO, Arménio. Empregados felizes são mais produtivos? Tékhne, Barcelos, $\mathrm{n}$. 12, p. 215-233, dez. 2009. Disponível em < http://www.scielo.mec.pt/scielo.php?script=sci_arttext\&pid=S1645-

99112009000200012\&lng=pt\&nrm=iso >. Acessos em 24 jul. 2019. Acesso em: 17/06/2019.

SANTOS, Milton. Por uma Outra Globalização. Do Pensamento Único à Consciência Universal. Rio de Janeiro: Record, 2001. Disponível em: < https://docs.google.com/viewer?a=v\&pid=sites\&srcid=ZGVmYXVsdGRvbWFpbnxlc3 R1ZGFudGVkb3JhdXNqdHxneDozMTI4YTM2ZTljOGI1OTQ5>. Acesso em: $17 / 06 / 2019$

SELIGMANN-SILVA, Edith. Saúde mental no trabalho contemporâneo. In Anais do 9o Congresso Internacional de Stress da ISMA-BR. 23-25 jun. 2009. Porto Alegre/RS.

TEODORO, Maria Cecília Máximo. A síndrome de patrão. In: Palestra proferida no IV Congresso Latino-americano de Direito Material e Processual do Trabalho. Punta Del Leste/Uruguai. 2015.2 Disponível em: https://www.migalhas.com.br/arquivos/2017/5/art20170503-05.pdf. Acesso em: $17 / 06 / 2019$

; DA SILVA, Thais Claudia D.'Afonseca; ANTONIETA, Maria. Disrupção, economia compartilhada e o fenômeno Uber. Revista da Faculdade Mineira de Direito, v. 20, n. 39, p. 1-30, 2017. https://doi.org/10.5752/P.23187999.2017v20n39p1-30

VAPIANA, Vitória Nassar; GOMES, Rogério Miranda; ALBURQUERQUE, Guilherme Souza Cavalcanti de. Adoecimento psíquico na sociedade contemporânea: notas conceituais da teoria da determinação social do processo saúde- doença. Saúde em Debate, v. 42, p. 175-186, 2018. https://doi.org/10.1590/0103-11042018s414

VIANA, Márcio Túlio; TEODORO, Maria Cecília Máximo. Misturas e fraturas do trabalho: do poder diretivo à concepção do trabalho como necessidade. Revista Brasileira de Estudos Políticos. v. 114, 2017. https://doi.org/10.9732/p.00347191.2017v114p299

ZUBOFF, Shoshana. Big Other: Capitalismo de Vigilância e Perspectivas Para Uma Civilização de Informação. In: Fernanda, et al. Tecnopolíticas Da Vigilância: Perspectivas da Margem. São Paulo: Boi Tempo, 2018. 